\title{
Conservation status of the order Rodentia of Brazil: taxonomic and biogeographical patterns
}

\author{
Estado de conservação da ordem Rodentia do Brasil: \\ padrões taxonômicos e biogeográficos
}

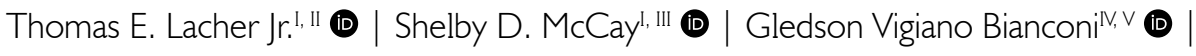 \\ Lilianna K. Wolf (D) | Nicolette S. Roach", "I (1) | Alexandre R. Percequillovl \\ 'Texas A\&M University. Department of Ecology and Conservation Biology. College Station, Texas, USA \\ "Global Wildlife Conservation. Austin, Texas, USA \\ IIITexas A\&M AgriLife Research. Natural Resources Institute. College Station, Texas, USA \\ IVInstituto Federal do Paraná. Pinhais, Paraná, Brasil \\ vNeotropical Institute. Research and Conservation. Curitiba, Paraná, Brasil
}

V'Universidade de São Paulo. Escola Superior de Agricultura “Luiz de Queiroz”. Departamento de Ciências Biológicas.

Piracicaba, São Paulo, Brasil

\begin{abstract}
The Global Mammal Assessment (GMA) evaluates the risk of extinction for all species of mammals, providing important data on their status to national and global conservation agencies and conventions. We assessed all of the species of Brazilian rodents as part of the GMA activities of the International Union for the Conservation of Nature Species Survival Commission (IUCN SSC) Small Mammal Specialist Group. A total of 234 species were evaluated against the IUCN Red List Criteria and placed into one of eight categories. Although rodents do not have elevated extinction risk compared to mammals as a whole, several families of caviomorph rodents have high levels of either threat, data deficiency, or both. The family Echimyidae has a large number of species and one-third of those either are species of conservation concern or data deficient. The family Ctenomyidae also is of concern in this regard. There are also strong geographic patterns to threat and poor knowledge. The focal areas for conservation effort are the Atlantic Forest and the Cerrado, and for Data Deficient species Atlantic Forest, Cerrado, and Amazonia, in particular the eastern Amazon. The results highlight the need for targeted field research and the application of ecological and spatial data to the development of conservation actions.
\end{abstract}

Keywords: Atlantic Forest. Biodiversity. Extinction risk. IUCN. Red list.

Resumo: AAvaliação Global de Mamíferos (GMA) é uma iniciativa da IUCN que gera informações sobre o risco de extinção para todas as espécies de mamíferos, fornecendo dados importantes às agências e convenções nacionais e globais de conservação. A partir da recente GMA, o Grupo de Especialistas em Pequenos Mamíferos da IUCN SSC (Species Survival Comission) avaliou todas as 234 espécies de roedores brasileiros em relação aos critérios da lista vermelha da IUCN, colocando-as em uma das oito categorias. Embora a ordem Rodentia não apresente risco elevado de extinção em comparação com os mamíferos como um todo, várias famílias de caviomorfos demonstram altos níveis de ameaça e/ou deficiência de dados. Para a família Echimyidae, que possui elevado número de espécies, um terço delas são preocupantes quanto à conservação ou com dados insuficientes. Ctenomyidae também é motivo de preocupação a esse respeito. Ademais, existem padrões geográficos consistentes de ameaças e pouco conhecimento. As áreas focais para os esforços de conservação são a Mata Atlântica e o Cerrado, e para as espécies com deficiência de dados, a Mata Atlântica, o Cerrado e a Amazônia, em particular o leste da Amazônia. Os resultados destacam a necessidade de pesquisas de campo direcionadas e a aplicação de dados ecológicos e espaciais no desenvolvimento de ações de conservação.

Palavras-chave: Mata Atlântica. Biodiversidade. Risco de extinção. IUCN. Lista vermelha.

LACHER, T. E., S. D. MCCAY, G. V. BIANCONI, L. K. WOLF, N. S. ROACH \& A. R. PERCEQUILLO, 2020. Conservation status of the order Rodentia of Brazil: taxonomic and biogeographical patterns. Boletim do Museu Paraense Emílio Goeldi. Ciências Naturais 15(3): 535-556. DOI: http://doi.org/10.46357/bcnaturais.v15i3.234.

Autor para correspondência: Thomas E. Lacher Jr. Texas A\&M University. Department of Ecology and Conservation Biology. College Station, Texas, USA 77843-2258 (tlacher@tamu.edu).

Recebido em 10/12/2019

Aprovado em 30/10/2020

Responsabilidade editorial: Alexandra Maria Ramos Bezerra
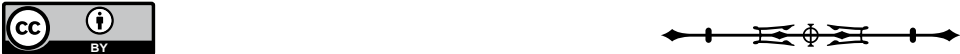


\section{INTRODUCTION}

Rodents represent about $40 \%$ of all living mammal species, comprising close to 2,500 species divided into 34 families (Lacher et al., 2016). However, things such as access to large datasets of species, and advances in phylogenetic methodology and molecular techniques have led to frequent taxonomic revisions, and the number of scientifically recognized species is in constant flux (Wilson \& Reeder, 2005; Chiquito et al., 2014; Burgin et al., 2018; Chiquito \& Percequillo, 2019). In Brazil, rodents are represented by about 257 species in nine families, and, in total, rodents make up approximately $34 \%$ of all Brazilian mammals (755 species) (Paglia et al., 2012; Percequillo et al., 2017; Abreu-Jr. et al., 2020).

In addition to the large number of taxa, rodents are diverse in their morphology, physiology and behavior. Their life histories are directly influenced by their diet, and rodent diets are diverse, encompassing carnivory, insectivory, omnivory, granivory, generalist herbivory and specialist herbivory (Nowak, 1999; Samuels, 2009). Their diversity allows them to occupy different ecological niches and play vital roles in the functioning of ecosystems (Asquith et al., 1999; Keesing, 2000; Zeng et al., 2019).

Like other mammalian groups, rodents face conservation challenges through the threats of global habitat loss and degradation, including impacts such as fragmentation, defaunation, climate change, and their synergistic effects. These threats to conservation are particularly pronounced in tropical ecosystems (Galetti et al., 2013; Dirzo et al., 2014; Peres et al., 2016; ICMBio, 2018; Bovendorp et al., 2019). Increased extinction threats facing rodents are especially concerning since they are among the least well researched group of all Brazilian vertebrates (Cassano et al. , 2017; Percequillo et al., 2017). These gaps in available data are a problem, as they impair the development of species conservation plans (Jetz \& Freckleton, 2015).

The IUCN Red List was established in 1964 and the first two volumes of Red Data Book by the International
Union for the Conservation of Nature (IUCN) were published in 1966 on global assessments of mammals and birds. Following these initial records, country-led initiatives for national list making became increasingly common (Scott et al., 1987; Vié et al., 2008). The first Brazilian initiatives to protect mammalian species by categorizing them under a conservation priority status began with Carvalho (1968) and Coimbra-Filho \& Magnanini (1968). Carvalho's list (1968) grounded the protection of species through the first federal ordinance (Brasil, 1968) which listed 18 species, with the absence of only one land mammal initially listed by Carvalho, the Short-eared Dog Atelocynus microtis (Sclater, 1883) (Machado, 2008). The IUCN threat categories that describe extinction risk were first adopted in Brazil in 1971 (Machado, 2008; Souza et al., 2018). On that occasion Coimbra-Filho (1972) presented a list of 27 mammals included in two threat categories as recommended by Species Survival Commission: species in imminent danger and vulnerable. Also, this was the first time Brazil cited rodents as threatened (vulnerable) including the Pacarana Dinomys branickii Peters, 1873, and the Bristlespined Rat Chaetomys subspinosus (Olfers, 1818), with the latter considered by Coimbra-Filho (1972) as the most sensitive. Along with R. A. Mittermeier, Coimbra-Filho was responsible for the Brazilian mammal dataset delivered to the IUCN Global Red List of Threatened Species, in 1974 (see Mittermeier et al., 2005).

Five national assessments of threatened species have been published in Brazil by the federal agencies the Brazilian Institute for Forestry Development (IBDF), that later gave origin to the Brazilian Institute of Environment and Natural Resources (IBAMA), and the Ministry of the Environment(MMA) (Brasil, 1968, 1973, 1989, 2003, 2014) and the country's last two assessments (2003 and 2014) were based on "The 2001 IUCN Red List Categories and Criteria: Version 3.1" (IUCN, 2001). The 2014 Brazilian report assessed a total of 244 rodents with eight species categorized as Vulnerable, 19 as Endangered, three as Critically Endangered, and 29 as Data Deficient (Brasil, 2014;

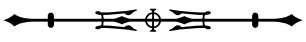


ICMBio, 2018). The Brazilian lists through every iteration exhibited an increasing quality of assessments involving hundreds of specialists and institutions in the evaluation process. There were 28 specialists involved with rodents alone in the 2014 list. They were decidedly very useful in guiding conservation work at sub-global levels.

IUCN, through its Global Species Program (IUCN, n. d.a) and the Species Survival Commission (IUCN, n. d.b), assesses the risk of extinction of animal, plant and fungi taxa at the global level. After the launch of "The 2001 IUCN Red List: Categories and Criteria: Version 3.1" (IUCN, 2020a), all global assessments have been based on the rules outlined in this document. Five quantitative criteria are used to assess the extinction risk of a given species classifying it into one of nine risk categories. Every species of mammals, including 2,255 rodent species, were first assessed and classified according to these categories and criteria (Version 3.1) in 2008 (Schipper et al., 2008). This study showed that $15.8 \%$ (258 species) of rodents assessed were in one of the IUCN categories of threat (Vulnerable, Endangered, or Critically Endangered) and 16\% (368 species) had insufficient information for a proper assessment of their conservation status, and were therefore classified as Data Deficient.

Red List assessment data are one of the main biodiversity indicators used by the signatories of the Convention on Biological Diversity (CBD), Brazil among them, and other international conventions in order to monitor progress towards national and global biodiversity conservation goals. Successive global assessments are used in the calculation the Red List Index (Butchart et al., 2005) to track trends risk of extinction these species face over time. The IUCN SSC Small Mammal Specialist Group (SMSG) led by four of the authors of this manuscript (SDM, NSR, ARP, TEL) assessed all New World species of orders Rodentia and Eulipotyphyla. Here, we present the results of our status assessments for Brazilian rodent species, including spatial patterns of threat and data deficiency in relation to the principal Brazilian biomes.

\section{METHODS}

\section{IUCN RED LIST ASSESSMENTS}

We conducted our assessments following the guidelines of the International Union for the Conservation of Nature Red List (IUCN Red List) Categories and Criteria: Version 3.1 (IUCN, 2001). We assessed 1,138 New World species of which 1,031 were rodents. The total number of rodents assessed for Brazil was 234 from nine families (sensu Wilson \& Reeder, 2005; Wilson et al., 2016, 2017).

The steps to conduct a single species assessment following IUCN Red List guidelines are as follows (Figure 1).

1) Pre-assessment: the specialist group identifies Red List Authorities to assist in the assessments and the timeline is agreed upon for assessment review. Data source review and data compiled in the Species Information Service (SIS) by project staff, expert consultants, and project participants (SIS, n. d.). When assessments are completed, the information is downloaded into the species accounts and is made publically available on the IUCN Red List website (IUCN, 2020b);

2) Assessment: draft assessments are prepared in SIS through workshops, review, and consistency checks. Post-workshop review and consistency checks are also carried out;

3) Review: draft assessments in SIS are referred to Red List Authorities for assessment review;

4) Submission: all assessments from Red List Authorities, Global Species Programme, and Partner projects are submitted via SIS. The Red List Unit in Cambridge, UK (IUCN, 2020c), scans assessments submitted for obvious errors and checks consistency between projects. The Red List Unit checks criteria use, supporting documentation and consistency, proofreading, and formatting for: - reviewed assessments for Red List Authorities; - unreviewed assessments from outside IUCN SSC network;

5) Publication: assessments are then added to the SIS database and appear on the appropriate IUCN Red List website update (IUCN, 2020b), accessible to the public.

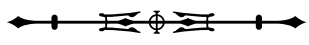




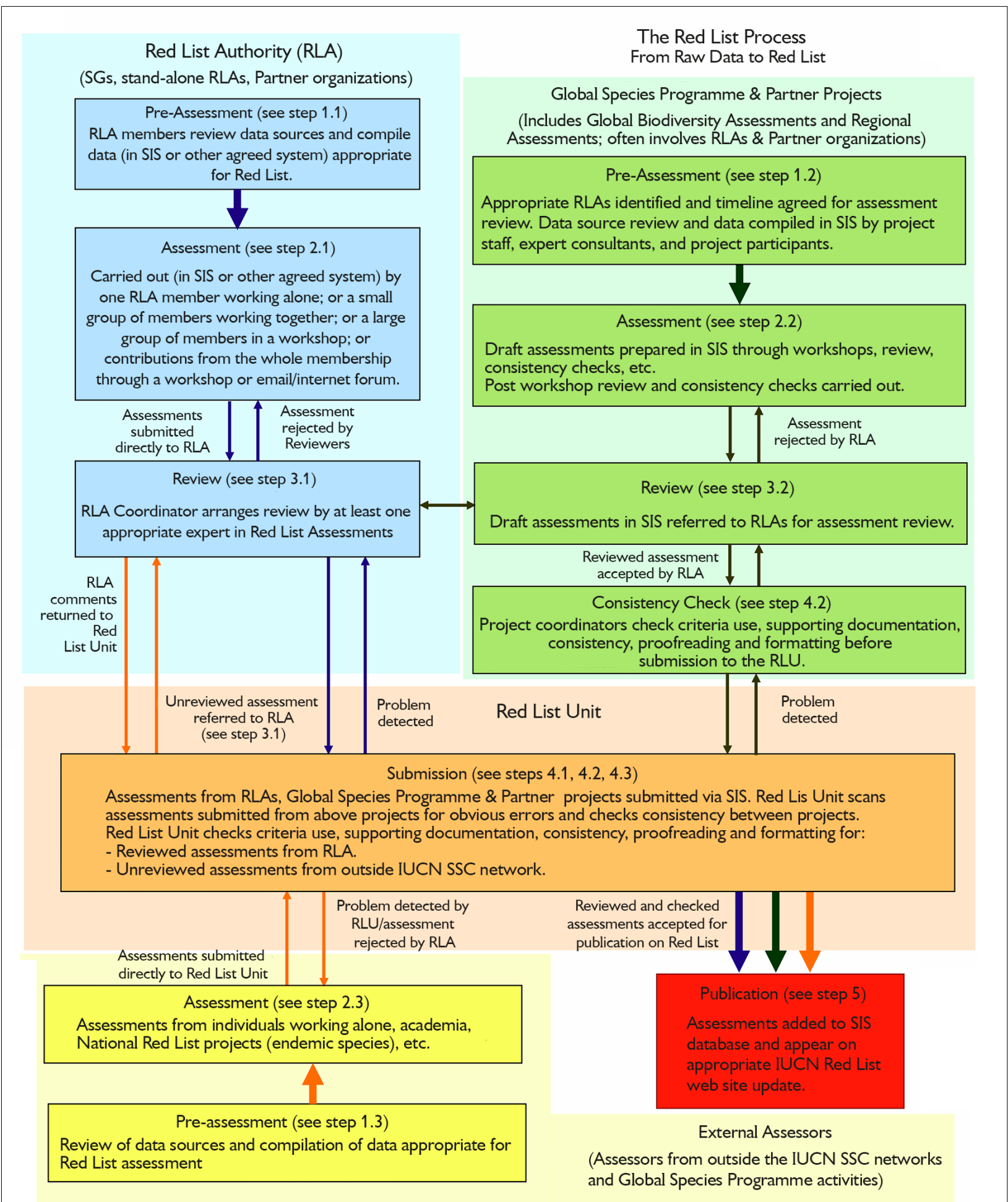

Figure 1. The IUCN Red List Species Assessment Process. The primary pathway used by the SMSG followed as outlined in the blue box. Used with permission of the IUCN Red List Unit, Cambridge, UK.

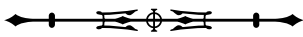


In preparation for publication, assessed species are ranked on a scale according to their threat of extinction (Figure 2). The species of highest concern of being at risk of extinction are listed in the 'Threatened' subcategory. Within the 'Threatened' subcategory there are three assignations of increasing conservation concern: 'Vulnerable', 'Endangered', and 'Critically Endangered'. The 'Near Threatened' category consists of species that are assessed to be on the brink of being assessed under a Threatened subcategory. For the purposes of this paper, we also considered the 'Near Threatened' category as part of our species of conservation concern.

\section{BRAZILIAN SMALL MAMMAL SPECIES ASSESSMENTS}

We coordinated and conducted assessments individually for each species of Brazilian Rodentia by IUCN Red List trained assessors in the Texas A\&M University Unit of the IUCN SSC Small Mammal Specialist Group. All assessors were required to pass the on-line training course available at the website The Nature Conservancy (2019). In the past, assessments were frequently conducted collaboratively in organized workshops, however, the 2019 assessments lacked the funds necessary for assessment workshops and assessors instead contributed their work via the SMSG team using the Species Information Service (SIS) online toolkit. The SIS toolkit is a collaborative database used for species assessments. Trained participating assessors are granted access to the interface by the Global Mammal Assessment (GMA) housed at Sapienza University of Rome, Italy. These assessors are then assigned species for which to gather information and then draft a report of an assessment in collaboration with the Small Mammal Specialist Group (SMSG) at Texas A\&M University. Final assessment report drafts are then sent to the

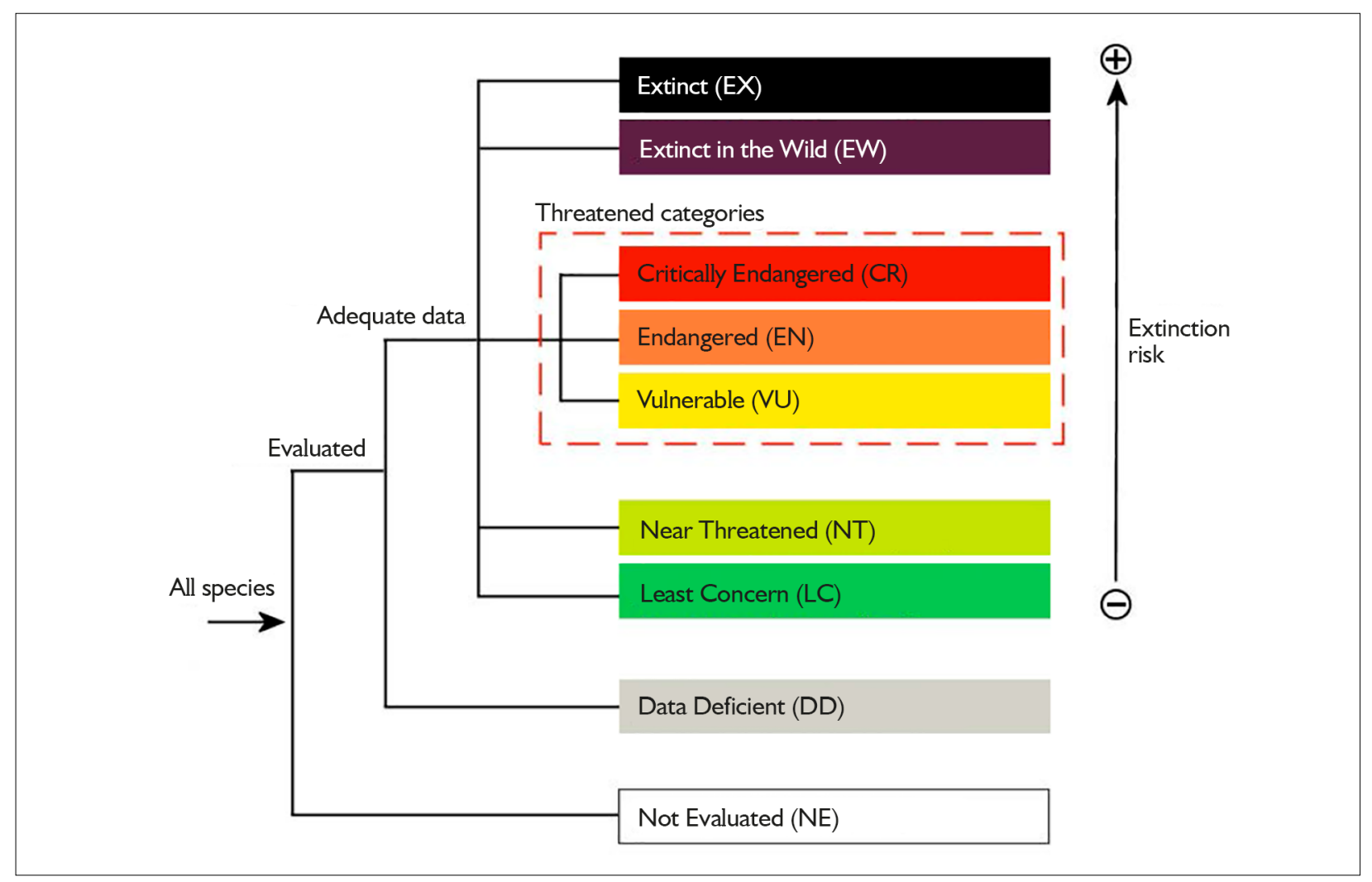

Figure 2. The IUCN Red List Categories. Used with permission of the IUCN Red List Unit, Cambridge, UK.

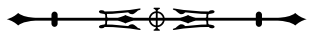


GMA, who reviews reports and provides edits. These are often returned to the SMSG team for additional changes or research. The assessments are then sent to the IUCN Red List Unit in Cambridge for final review and approval before being published on the IUCN Red List website.

Organizing assessors electronically was often difficult. Few Brazilian assessors were certified through the IUCN Red List training and subsequent examination and therefore had no access to the SIS system, and instead had to collaborate with colleagues who had access and were able to complete and consolidate reports. A large portion of the effort to complete these assessments was spent organizing assessors and their data, and connecting them to colleagues who consolidated their reports within the SIS system.

The Texas A\&M Small Mammal Specialist Group Assessment Team (SMSG) consolidated information for all Brazilian Rodentia species included in this assessment. The SMSG then took the collection of reports and made range maps of most assessed species in this report - some range maps were provided from Mammals of South America (Patton et al., 2015), others from Volumes 6 and 7 of the Handbook of Mammals of the World (Wilson et al., 2016, 2017), as well as other regional treatises on mammals and the primary literature. Brazilian assessors also provided point locality data and revisions to previous published range maps.

Heat maps of the density of species of conservation concern and data deficiency were generated in ArcGIS using the spatial data from the IUCN Red List website.

\section{RESULTS}

\section{ASSESSMENT OF ALL SPECIES OF RODENTIA IN BRAZIL}

We conducted assessments of all species of Brazilian rodents documented between 2015 and 2019. As a consequence, recently described species are not included in the data compiled for this analysis. There were 80 species assessed in the present study that were not assessed in the 2008 Global Mammal Assessment (Table 1 and supplemental material'; Schipper et al., 2008). The 80 new species were assessed using Red List criteria by the SMSG. The relative distribution of species among categories remained fairly consistent with the exception of a $40 \%$, but numerically small, drop in Vulnerable (VU) species. The greatest increase was in the number of Least Concern (LC) species, as most of the 80 newly assessed species fell into this category. There was a total of 24 species we considered of conservation concern: 20 in one of the three threatened categories and four listed as Near Threatened.

We evaluated the current status of all rodents by family, both for species of conservation concern and Data Deficiency (Table 2). The families Caviidae, Ctenomyidae, Echimyidae, and Erethizontidade have a higher percentage of species of conservation concern than the percentage for rodents as a whole, and these same four families have a higher than expected percentage of Data Deficient (DD) species than for rodents as a whole. The family Echimyidae,

Table 1. Number of species of rodents by IUCN Category in 2008 and the present study with percentage of change in each category. There were 80 new assessments in the present study. Legends: NE $=$ not evaluated; $\mathrm{DD}=$ data deficient; $\mathrm{LC}=$ least concern; $\mathrm{NT}$ $=$ near threatened; $\mathrm{VU}=$ vulnerable; $\mathrm{EN}=$ endangered; $\mathrm{CR}=$ critically endangered; $\mathrm{EX}=$ extinct.

\begin{tabular}{c|c|c|c}
\hline Category & 2008 & Present & \% Change \\
\hline NE & 80 & 0 & - \\
\hline DD & 35 & 40 & 14.3 \\
\hline LC & 92 & 168 & 82.6 \\
\hline NT & 2 & 4 & 100.0 \\
\hline VU & 10 & 6 & -40.0 \\
\hline EN & 10 & 11 & 10.0 \\
\hline CR & 3 & 3 & 0.0 \\
\hline EX & 2 & 2 & 0.0 \\
\hline Total & 234 & 234 & - \\
\hline
\end{tabular}

\footnotetext{
1 See complementary material to this article, in a table available at link: http://editora.museu-goeldi.br/bn/artigos/cnv15n3_2020/Lacher
} et al_suppl.xlsx

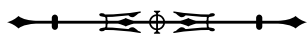


Table 2. The number of species of rodents by family in each IUCN Red List Category in the present reassessment. Families with superscript 1 indicate an elevated number of species of conservation concern (NT, VU, EN, CR); families with superscript 2 indicate an elevated percentage of DD; and families with superscript 3 an elevated number of species both of conservation concern and DD species. Legends: $\mathrm{NE}=$ not evaluated; $\mathrm{DD}=$ data deficient; $\mathrm{LC}=$ least concern; $\mathrm{NT}=$ near threatened; $\mathrm{VU}=$ vulnerable; $\mathrm{EN}=$ endangered; $\mathrm{CR}=$ critically endangered; EX = extinct; ${ }^{*}=$ there are also two Least Concern species of Muridae, not native to Brazil.

\begin{tabular}{l|c|c|c|c|c|c|c|c}
\hline \multicolumn{1}{c|}{ Family } & DD & LC & NT & VU & EN & CR & EX & Species number \\
\hline Caviidae $^{1}$ & 1 & 7 & 0 & 0 & 0 & 1 & 0 & 9 \\
\hline Cricetidae $^{\text {Ctenomyidae }}{ }^{3}$ & 17 & 97 & 3 & 4 & 3 & 0 & 2 & 126 \\
\hline Cuniculidae $^{2}$ & 2 & 2 & 0 & 1 & 1 & 0 & 0 & 6 \\
\hline Dasyproctidae $^{2}$ & 4 & 5 & 0 & 0 & 0 & 0 & 0 & 1 \\
\hline Dinomyidae $^{\text {Echimyidae }}$ & 0 & 1 & 0 & 0 & 0 & 0 & 0 & 9 \\
\hline Erethizontidae $^{3}$ & 12 & 42 & 1 & 0 & 6 & 2 & 0 & 1 \\
\hline Sciuridae & 3 & 5 & 0 & 1 & 1 & 0 & 0 & 63 \\
\hline Total & 1 & 6 & 0 & 0 & 0 & 0 & 0 & 7 \\
\hline
\end{tabular}

with 19\% DD species and $14.3 \%$ species of conservation concern is of particular importance of additional basic research and conservation action.

\section{SPECIES OF CONSERVATION CONCERN ACCOUNTS}

Of the 24 species of conservation concern, 16 are restricted to the Atlantic Forest and two more occur both there and in the Cerrado. Two other species are restricted to the Cerrado, and two others in the Pampas region of southern Brazil (Table 3). This highlights the need for concerted conservation efforts in the Brazilian Atlantic Forest. Detailed accounts for all 24 species follow. Common names are those presented on the IUCN Red List accounts.

\section{Caviidae}

Cavia intermedia Cherem, Olimpio \& Ximenez, 1999

- Santa Catarina's Guinea Pig

IUCN Red List: CR D / Brazil: CR B1ab(iii) + 2ab(iii);

D / Santa Catarina: CR.

Description: this species is only found only on llhas Moleques do Sul, a continental island that is part of the Parque Estadual da Serra do Tabuleiro, a large conservation unit that includes hills, coastal lowlands, and several coastal islands. Its total distribution is only 4 hectares - the smallest area of occurrence of any known mammal in the world. It has an average estimated population size of 42 individuals (Salvador \& Fernandez, 2008; Lacher, 2016; Roach, 2016).

Major threats: hunting is presumed to be a threat to Santa Catarina's Guinea Pig, but fire and species introductions may also represent major threats. Given its extremely small population size and restricted distribution, it is highly vulnerable to natural disasters.

Current conservation efforts: the species is monitored, and the population appears stable. The Park and all available habitats have been designated as a Preservation Zone where entry is prohibited. Nevertheless, management and enforcement are ineffective; the most urgent conservation need is to guarantee full protection and enforcement of restricted access and possible monitoring and restoration of its key herbaceous and grassland food base (Lacher, 2016; Roach, 2016). Species listed as CR in Brazil (Brasil, 2014); included in the Santa Catarina's List of Threatened Species in category CR (São Paulo, 2011); and recently addressed in the "Plano de Ação Estadual para a Conservação do Preá-de Moleques-do-Sul" (Santa Catarina, 2019). 
Table 3. Summary of the 24 Species of Conservation Concern, with data of distribution, conservation status, and threats. Brazil and State List columns marked '-' had no federal or state evaluation. Occurrence and federative unit codes: AL = Alagoas; BA = Bahia; DF = Distrito Federal; ES = Espírito Santo; GO = Goiás; MG = Minas Gerais; PE = Pernambuco; PB = Paraíba; PR = Paraná; RJ = Rio de Janeiro; RO = Roraima; RS = Rio Grande do Sul; SC = Santa Catarina; SE = Sergipe; SP = São Paulo. Biomes: AF = Atlantic Forest; AM $=$ Amazon; $\mathrm{CA}=$ Caatinga; $\mathrm{CE}=$ Cerrado; $\mathrm{PA}=$ Pampa. Categories of Threat: $\mathrm{VU}=$ Vulnerable; $\mathrm{EN}=$ Endangered; $\mathrm{CR}=\mathrm{Critically}$ Endangered; $\mathrm{PE}=$ Possibly Extinct.

\begin{tabular}{|c|c|c|c|c|c|c|}
\hline Taxon & Occurrence & Biome & Endemic & $\begin{array}{c}\text { Brazil } \\
\text { list }\end{array}$ & State list & Principal threats \\
\hline \multicolumn{7}{|l|}{ CAVIIDAE } \\
\hline Cavia intermedia & SC (island) & $\mathrm{AF}$ & Yes & $C R$ & $\mathrm{SC}(\mathrm{CR})$ & Small and restricted population \\
\hline \multicolumn{7}{|l|}{ CRICETIDAE } \\
\hline $\begin{array}{l}\text { Drymoreomys } \\
\text { albimaculatus }\end{array}$ & SP to SC & $\mathrm{AF}$ & Yes & - & - & Habitat degradation, forest fragmentation \\
\hline Euryoryzomys lamia & MG, GO & CE & Yes & EN & $M G(C R)$ & Agriculture and extraction of timber \\
\hline Hylaeamys laticeps & BA to RJ & $\mathrm{AF}$ & Yes & - & - & Agriculture, forest degradation, urbanization \\
\hline Hylaeamys oniscus & $\mathrm{AL}, \mathrm{PE}, \mathrm{PB}$ & $\mathrm{AF}$ & Yes & - & - & Sugar cane, other agriculture, fragmentation \\
\hline Juliomys rimofrons & RJ, MG, SP & $\mathrm{AF}$ & Yes & - & - & Habitat degradation, forest fragmentation \\
\hline $\begin{array}{l}\text { Microakodontomys } \\
\text { transitorius }\end{array}$ & DF & CE & Yes & EN & - & Urban expansion, population isolation \\
\hline Phaenomys ferrugineus & $M G, R J, S P$ & $\mathrm{AF}$ & Yes & - & $\mathrm{SP}(\mathrm{VU})$ & Decline in the quality or extension of habitat \\
\hline Podoxymys roraimae & $\mathrm{RO}$ & AM & No & - & - & Tourism and extraction of timber \\
\hline Rhagomys rufescens & $\begin{array}{l}\text { MG, ES, RJ, } \\
\text { SP, SC }\end{array}$ & $\mathrm{AF}$ & Yes & - & $\mathrm{RJ}(\mathrm{PE})$ & Habitat degradation forest fragmentation \\
\hline Wilfredomys oenax & SP, PR, RS & $\mathrm{AF}$ & No & EN & $\begin{array}{l}\mathrm{PR}(\mathrm{CR}) \\
\mathrm{RS}(\mathrm{EN})\end{array}$ & Habitat degradation forest fragmentation \\
\hline \multicolumn{7}{|l|}{ CTENOMYIDAE } \\
\hline Ctenomys flamarioni & RS & PA & Yes & EN & $\mathrm{RS}(\mathrm{EN})$ & Domestic animals, urbanization, extraction of sand \\
\hline Ctenomys lami & RS & PA & Yes & EN & RS (EN) & Urbanization, agriculture \\
\hline \multicolumn{7}{|l|}{ ECHIMYIDAE } \\
\hline Callistomys pictus & BA & $\mathrm{AF}$ & Yes & EN & $\mathrm{BA}(\mathrm{EN})$ & Disturbance of native forest, mixed agroforestry, cabruca \\
\hline Phyllomys brasiliensis & MG & AF/CE & Yes & EN & $M G(E N)$ & Decline in the quality or extension of habitat \\
\hline Phyllomys lundi & $M G, R J$ & $\mathrm{AF}$ & Yes & EN & MG (EN) & Decline in the quality or extension of habitat \\
\hline $\begin{array}{l}\text { Phyllomys } \\
\text { mantiqueirensis }\end{array}$ & MG & $\mathrm{AF}$ & Yes & - & - & Restricted and decline in quality or extension of habitat \\
\hline Phyllomys thomasi & SP (island) & $\mathrm{AF}$ & Yes & EN & $\mathrm{SP}(\mathrm{EN})$ & Restricted habitat, urbanization, domestic animals \\
\hline Phyllomys unicolor & BA & $\mathrm{AF}$ & Yes & CR & $\mathrm{BA}(\mathrm{CR})$ & Agriculture, decline in quality or extension of habitat \\
\hline Trinomys eliasi & $\mathrm{RJ}$ & $\mathrm{AF}$ & Yes & VU & $\mathrm{RJ}(\mathrm{EN})$ & Human pressure, habitat alteration, extraction of sand \\
\hline
\end{tabular}


Table 3.

(Conclusion)

\begin{tabular}{|c|c|c|c|c|c|c|}
\hline Taxon & Occurrence & Biome & Endemic & $\begin{array}{c}\text { Brazil } \\
\text { list }\end{array}$ & State list & Principal threats \\
\hline Trinomys moojeni & MG & AF/CE & Yes & EN & $M G(V \cup)$ & Decline in the quality or extension of habitat, fire \\
\hline Trinomys yonenagae & BA & CA & Yes & EN & $\mathrm{BA}(\mathrm{EN})$ & Loss of habitat, especially extraction of sand \\
\hline \multicolumn{7}{|l|}{ ERETHIZONTIDAE } \\
\hline Chaetomys subspinosus & SE to RJ & $A F$ & YES & VU & $\begin{array}{l}\mathrm{BA}(\mathrm{VU}) \\
\mathrm{ES}(\mathrm{VU})\end{array}$ & Decline in the quality or extension of habitat \\
\hline Coendou speratus & $\mathrm{PE}, \mathrm{AL}$ & $\mathrm{AF}$ & YES & EN & - & Forest fragmentation, restricted to small fragments \\
\hline
\end{tabular}

\section{Cricetidae}

Drymoreomys albimaculatus Percequillo, Weksler \& Costa, 2011 - White-throated Montane Forest Rat IUCN Red List: NT B1ab(iii) + 2ab(iii).

Description: this species is a specialist of premontane forests in the coastal Brazilian Atlantic Rainforest from São Paulo and Rio de Janeiro to Santa Catarina states, in altitudes ranging between 650 and 1,200 meters including a register for the Serra da Bocaína National Park in a mixed habitat of forest and bamboo (Percequillo et al., 2011; Delciellos et al., 2015). While found to inhabit secondary and disturbed forests, literature suggests it needs access to pristine forest to sustain its population (Percequillo \& Weksler, 2015).

Major threats: as with all inhabitants of the Atlantic Forest biome, this species is vulnerable to the effects of habitat loss (Engelbrektsson, 2019).

Current conservation efforts: while this species occurs in protected areas (Engelbrektsson, 2019), there are no existing conservation plans specific for it.

Euryoryzomys lamia (Thomas, 1901) - Buffy-sided

Euryoryzomys

IUCN Red List: VU B2ab(i,iii) / Brazil: EN B1ab(iii) / Minas Gerais: CR.

Description: this forest-dwelling species is only recorded existing in four localities in the states of western Minas Gerais and southern Goiás. Of these four localities, two no longer support viable habitat, as their forest has been completely destroyed by agricultural land use change (Percequillo, 2015a; Percequillo \& Weksler, 2018).

Major threats: this species faces threats from habitat destruction due to agriculture and logging activities.

Current conservation efforts: while this species occurs in the protected area Parque Nacional da Chapada dos Veadeiros (Bonvicino et al., 2005), there are no existing conservation plans specific to this species. Species is listed as EN in Brazil (Brasil, 2014) and included in the state of Minas Gerais List of Threatened Species in category CR (Minas Gerais, 2010).

Hylaeamys laticeps (Lund, 1840) - Atlantic

Forest Hylaeamys

IUCN Red List: VU B2ab(i,ii,iii).

Description: this species occurs in the lowlands of the Atlantic Rainforest, from Bahia to Rio de Janeiro (Weksler et al., 1999; Percequillo \& Weksler, 2019).

Major threats: this species faces threats from deforestation, urbanization, and agriculture (Percequillo, 2015b; Percequillo \& Weksler, 2019).

Current conservation efforts: while this species occurs in protected areas including the Rio Doce State Park in Minas Gerais (Percequillo, 2015b; Percequillo \& Weksler, 2019), there are no existing conservation plans specific for it. Note that Percequillo (2015b) considers Hylaeamys seuanezi (Weksler, Geise \& Cerqueira, 1999) to be synonymous with $\mathrm{H}$. laticeps, disputed by Brennand et al. (2013). In fact, Brennand et al. (2013) are correct in their 
decision and the appropriate the name for this species is $\mathrm{H}$. seuanezi, with $H$. laticeps currently under the synonymy of H. megacephalus Fischer, 1814.

Hylaeamys oniscus (Thomas, 1904) - Northern Atlantic Forest Hylaeamys

IUCN Red List: NT B2ab(iii).

Description: this species only exists in the northeastern part of the Atlantic Rainforest, north of the Rio São Fransciso in the states of Alagoas, Pernambuco, and Paraíba (Percequillo, 2015b). The remaining habitat for this species is highly fragmented. The species has only been captured in the forest, and not in surrounding developed areas, suggesting that this species is entirely reliant on dense forest habitat (Percequillo \& Roach, 2017).

Major threats: the majority of this species' habitat has been developed and converted for sugar cane, ranching, and other agricultural activities. What is left of this species's habitat is severely fragmented (T. Lacher Jr., personal communication).

Current conservation efforts: while this species occurs in protected areas, including the Estação Ecologia de Murici, Alagoas state, and Reserva Biológica de Saltinho, Pernambuco state (Percequillo \& Roach, 2017), there are no existing conservation plans specific for it.

Juliomys rimofrons Oliveira \& Bonvicino, 2002 - Cleftheaded Juliomys

IUCN Red List: NT B1a+2a.

Description: this rare, arboreal species is believed to be endemic to high altitude areas connecting along the borders of the states of Rio de Janeiro, Minas Gerais, and São Paulo. This species has only been observed in the wild thrice over the course of an eight-year survey project - although, this could be the result of misguided trapping methodology (Bonvicino \& Geise, 2008; Fonseca et al., 2013).

Major threats: although this species faces no immediate threats, its restricted range in few remaining protected areas suggest that it was likely more widespread in the past, and the remaining populations need protection (Naylor \& Roach, 2019).

Current conservation efforts: records of these species show them mainly occurring in protected national parks, however, there are no existing conservation plans specific for it.

Microakodontomys transitorius Hershkovitz, 1993 -

Transitional Colilargo

IUCN Red List: EN B2ab(iii) / Brazil: EN B1ab(iii) + 2ab(iii).

Description: it is endemic to Brazil and was known only from the type locality: Brazil, Federal District, Parque Nacional de Brasilia, 1,100 m (Eisenberg \& Redford, 1999; Paresque \& Hanson, 2015). Another four individuals were collected in the Área Alfa da Marinha, ca. 170 km NW Parque Nacional de Brasilia, near to the Área de Proteção Ambiental (APA) das Bacias do Gama e Cabeça de Veado (ICMBio, 2018).

Major threats: it is assumed that $M$. transitorius is a rare species and its population is severely fragmented because the landscape between its two registration sites includes habitat degraded by urban growth (Paresque \& Hanson, 2015; ICMBio, 2018). Environmental and ecological impacts may to be larger than acceptable.

Current conservation efforts: although the landscape of its territory is affected by human activities, where the quality of the habitat is decreasing, $M$. transitorius occurs in one protected area: Parque Nacional de Brasília. Microakodontomys transitorius is listed as EN in Brazil (Brasil, 2014).

Phaenomys ferrugineus (Thomas, 1894) - Rio de

Janeiro Arboreal Rat

IUCN Red List: EN B2ab(ii,iii) / São Paulo: VU.

Description: this species appears to be endemic to Atlantic Forest of southeastern Brazil and it is known only from restricted areas in the states of Minas Gerais, Rio de Janeiro and São Paulo, mainly of montane forest (Passamani et al., 2011; Percequillo, 2015c). 
Major threats: it may be restricted to the region of the Serra da Mantiqueira and Serra da Bocaina range and surrounding areas (Passamani et al., 2011). The major threat to this species is continuing decline in the extent and quality of its habitat.

Current conservation efforts: Phaenomys ferrugineus occurs in six protected areas: Parque Nacional de Itatiaia, Estação Ecológica de Bananal, Parque Estadual dos Três Picos, Área de Proteção Ambiental Floresta do Jacarandá, Parque Nacional da Serra dos Órgãos, and Parque Nacional da Serra da Bocaina. The species has been included in the Conservation Action Planning of Central Atlantic Forest Mammals (Escarlate-Tavares et al., 2016) and it is included in the São Paulo's List of Threatened Species in category VU (São Paulo, 2018).

Podoxymys roraimae Anthony, 1929 -

Roraima Akodont

IUCN Red List: VU D2.

Description: this species is only documented on the Venezuelan side of Mount Roraima, but its range likely extends across the Brazilian border in the northern part of the state of Roraima. All specimens of this species have been documented in areas with growth of Bonnettia trees (Patton, 2018).

Major threats: timber extraction and tourism threatens this species' habitat (Linares, 1998).

Current conservation efforts: this species likely occurs in the Parque Nacional do Monte Roraima (Paglia et al., 2012).

\section{Rhagomys rufescens (Thomas, 1886) - Rufescent}

Rhagomys

IUCN Red List: VU B2ab(i,ii,iii) / Rio de Janeiro: Possibly Extinct.

Description: this species occurs in the Atlantic Rainforest in Minas Gerais, Espírito Santo, part of Rio de Janeiro, São Paulo, and Santa Catarina states in Brazil (Patton et al., 2015; Bergallo \& Percequillo, 2019). Little is known of this species' ecology and life history.
Major threats: like many species endemic to the Atlantic Rainforest, this species faces major threats from habitat destruction and fragmentation.

Current conservation efforts: this species occurs in protected areas (Núcleo Picinguaba of the Parque Estadual da Serra do Mar, Estação Ecológica do Bananal in São Paulo state) and has been included in the Conservation Action Planning of Central Atlantic Forest Mammals (EscarlateTavares et al., 2016). It is cited as probably extinct in Rio de Janeiro, its type locality (Bergallo et al., 2000).

\section{Wilfredomys oenax (Thomas, 1928) - Red-nosed}

Tree Mouse

IUCN Red List: EN B2ab(ii,iii,iv) / Brazil: EN B2ab(ii,iii) / Paraná: CR / Rio Grande do Sul: EN.

Description: this species occurs from Brazil to north and central Uruguay (Musser \& Carleton, 2005). In Brazil, it is known only from restricted areas in the states of Paraná, Rio Grande do Sul (ICMBio, 2018) and São Paulo (Brandão, 2015), without new records in Paraná and São Paulo states for over 38 and 70 years, respectively, even with significant rodent sampling (Brandão, 2015; ICMBio, 2018).

Major threats: the species is rare and very little is known about its status and habitat requirements. There is continuing decline in the extent and quality of its habitat across the entire distributional range.

Current conservation efforts: the species has been included in the Conservation Action Planning of Lake and Lagoon Systems of Southern Brazil (ICMBio, 2018). It is listed as EN in Brazil (Brasil, 2014) and included in the Paraná's List of Threatened Species in category CR (Paraná, 2010) and Rio Grande do Sul in EN (Rio Grande do Sul, 2014).

\section{Ctenomyidae}

Ctenomys flamarioni Travi, 1981 - Flamarion's

Tuco-tuco

IUCN Red List: EN B2ab(i,ii,iii,iv) / Brazil: EN Blab(i,iii) / Rio Grande do Sul: EN.

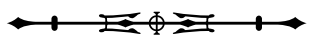


Description: it is endemic to Brazil occurring exclusively along the first coastal dune strip in Rio Grande do Sul state, an environment that has a high degree of salinity and poor vegetation cover (Freitas, 1995).

Major threats: its habitat has been altered by urbanization, sand mining and other activities. Human and domestic animal populations are also a threat to $C$. flamarioni (ICMBio, 2018).

Current conservation efforts: the species has been included in the Conservation Action Planning of Lake and Lagoon Systems of Southern Brazil (ICMBio, 2018). It is listed as EN in Brazil (Brasil, 2014) and included in the Rio Grande do Sul's List of Threatened Species in category EN (Rio Grande do Sul, 2014).

Ctenomys lami Freitas, 2001 - Lami Tuco-tuco IUCN Red List: VU Blab (i,ii,iii) / Brazil: EN B1ab (ii,iii) / Rio Grande do Sul: EN.

Description: this species occurs in multiple localities in the state of Rio Grande do Sul, especially on Lami beach in the Guaiba River. Most localities where this species is present have experienced anthropogenic development (Bidau, 2015).

Major threats: deforestation has resulted in the degradation of a previous natural barrier between Ctenomys lami and Ctenomys minutus Nehring, 1887. As such, a hybrid zone has opened up and threatens the integrity of the species Ctenomys lami (Gava \& Freitas, 2003). This species is also threatened by increased urbanization and agricultural development in its limited territory.

Current conservation efforts: it is listed as EN in Brazil (Brasil, 2014) and included in the Rio Grande do Sul's List of Threatened Species in category EN (Rio Grande do Sul, 2014).

\section{Echimyidae}

Callistomys pictus (Pictet, 1843) - Painted Tree Rat IUCN Red List: EN B2ab (i,ii,iii) / Brazil: EN B1ab (ii,iii) / Bahia: EN.
Description: it is endemic to the Atlantic Forest of coastal Bahia, where it is known for only four locations (Emmons et al., 2015; Fabre et al., 2016; ICMBio, 2018).

Major threats: the landscape is a mosaic inhabited by this species composed mainly of small forest fragments immersed in a matrix of shaded cocoa plantations (Saatchi et al., 2001). Disturbances of native forests and cocoa agroforestry still occur, and it represents a serious threat to the survival of Callistomys pictus.

Current conservation efforts: the species has been included in the Conservation Action Planning of Central Atlantic Forest Mammals (Escarlate-Tavares et al., 2016) and most recently has been included in the Bahia's List of Threatened Species in category EN (Cassano et al., 2017). It is listed as EN in Brazil (Brasil, 2014).

\section{Phyllomys brasiliensis Lund, 1840 - Brazilian Atlantic} Tree Rat

IUCN Red List: EN B2ab(i,ii,iii) / Brazil: EN B2ab(iii,iv) / Minas Gerais: EN.

Description: it is endemic to Brazil and extremely rare, occurring only in Minas Gerais (type locality is Lapa das Quatro Bocas, Lagoa Santa). Since the 19th century there are few records (only five) in regions of the Minas Gerais state, in the valleys of Paraopeba and das Velhas rivers (Fabre et al., 2016; Leite \& Loss, 2015; ICMBio, 2018).

Major threats: the major threat to this species is continuing decline in the extent and quality of its habitat. Species is not found in any protected areas.

Current conservation efforts: it is listed as EN in Brazil (Brasil, 2014) and included in the Minas Gerais' List of Threatened Species in category EN (Minas Gerais, 2010). The species has been included in the Conservation Action Planning of Central Atlantic Forest Mammals (EscarlateTavares et al., 2016).

Phyllomys lundi Leite, 2003 - Lund's Atlantic Tree Rat IUCN Red List: EN B1ab(iii) / Brazil: EN B2ab(iii,iv) / Minas Gerais: EN.

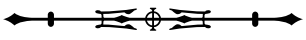


Description: it is endemic to southeastern Brazil and known only from two localities $200 \mathrm{~km}$ apart in the Minas Gerais and Rio de Janeiro states (Fabre et al., 2016; Leite \& Loss, 2015).

Major threats: the major threat to this species is continuing decline in the extent and quality of its habitat. An area of occupancy of the species was reduced by fire, so the species was classified as EN in Brazil (ICMBio, 2018).

Current conservation efforts: it is listed as EN in Brazil (Brasil, 2014) and included in the Minas Gerais' List of Threatened Species in category EN (Minas Gerais, 2010). One of the locations where the species was found is a protected area: Reserva Biológica de Poços das Antas, Rio de Janeiro.

Phyllomys mantiqueirensis Leite, 2003 - Serra da Mantiqueira Atlantic Tree Rat

IUCN Red List: CR Blab(iii).

Description: it is only found in a single area from mixed montane rainforest at 1,800 $\mathrm{m}$ altitude in limits of the Área de Proteção Ambiental (APA) da Mantiqueira, Minas Gerais, that belongs to the Brazilian Army (Leite, 2003).

Major threats: it may be restricted to high-elevation forests in the Serra da Mantiqueira, a very specific and naturally restricted habitat that has been continuing decline in area, extent and quality of habitat.

Current conservation efforts: the species' habitat is owned by the army for field training, this provides some degree of protection (Loss \& Leite, 2016a).

Phyllomys thomasi (Ihering, 1897) - Thomas's Atlantic Tree Rat

IUCN Red List: EN B1ab(iii)+2ab(iii) / Brazil: EN B1ab(iii) / São Paulo: EN.

Description: it is endemic to the Ilha de São Sebastião, São Paulo state, Brazil, a continental island where $80 \%$ is Atlantic Forest; the extent of occurrence is approximately $348 \mathrm{~km}^{2}$ - based on the area of the island (Eisenberg \& Redford, 1999; Fabre et al., 2016; ICMBio, 2018).
Major threats: the island, where the municipality of Ilhabela is inserted, has been severely urbanized with rapid and unordered population growth, occupation of forest areas, illegal burning, introduction of domestic animals, and tourism (ICMBio, 2018).

Current conservation efforts: it is listed as EN in Brazil (Brasil, 2014) and included in the São Paulo's List of Threatened Species in category EN (São Paulo, 2018). Phyllomys thomasi has been included in the Conservation Action Planning of Central Atlantic Forest Mammals (Escarlate-Tavares et al., 2016). Approximately $83 \%$ of the total area of the Island represents a protected area: Parque Estadual de Ilhabela.

Phyllomys unicolor (Wagner, 1842) - Unicolored Atlantic Tree Rat

IUCN Red List: CR B2ab(ii,iii) / Brazil: CR Blab / Bahia: CR PEX.

Description: it is endemic to Brazil and known only from the type specimen recorded in 1824. The type locality is Helvética, ca. $50 \mathrm{~km}$ SW Caravelas, Bahia, at elevation 59 meters (Emmons et al., 2002; Loss \& Leite, 2016b).

Major threats: it is known only from the holotype in only one locality that almost entirely represents an agriculture mosaic. This is a landscape that inevitably leads to localized declines in biodiversity (ICMBio, 2018).

Current conservation efforts: it was recently included in the Bahia's List of Threatened Species in category CR (Cassano et al., 2017) and is listed as CR in Brazil (Brasil, 2014). The species has been included in the Conservation Action Planning of Central Atlantic Forest Mammals (Escarlate-Tavares et al., 2016).

Trinomys eliasi (Pessôa \& Reis, 1993) - Elias's

Atlantic Spiny Rat

IUCN Red List: NT / Brazil: VU B1ab(ii,iii) / Rio de Janeiro: EN.

Description: this species occurs in the northeastern region of the state of Rio de Janeiro. The population 
is fragmented into multiple small populations within a restricted range (Brito \& Figueiredo, 2003; Pessôa et al., 2015). This solitary terrestrial species lives in semideciduous and evergreen forests (Pessôa et al., 2015).

Major threats: this species is vulnerable to human pressure from habitat destruction, especially in areas where its habitat is affected by sand extraction, and in areas where this species occurs in Barra de Maricá, which is used as a landfill for waste disposal (Brito \& Figueiredo, 2003).

Current conservation efforts: this species occurs in national parks, including Reserva Biológica Poço das Antas, Parque Nacional da Restinga de Jurubatiba, Reserva Particular do Patrimônio Natural Fazenda Santa Helena, and several others (ICMBio, 2018). The species is listed as VU in Brazil (Brasil, 2014) and included in the Rio de Janeiro's List of Threatened Species in category EN (Bergallo et al., 2000). Trinomys eliasi has been included in the Conservation Action Planning of Central Atlantic Forest Mammals (EscarlateTavares et al., 2016).

Trinomys moojeni (Pessôa, Oliveira \& Reis, 1992) Moojen's Atlantic Spiny Rat

IUCN Red List: EN B1ab(i,iii) / Brazil: EN B1ab(iii) / Minas Gerais: VU.

Description: it is endemic to Brazil restricted to the east-central Minas Gerais, in the southern Espinhaço massif. Trinomys moojeni occurs in forest lands above 1,000 m and is present at the border between the Cerrado and Atlantic Forest (Roach \& Naylor, 2016). It has been reported from the Parque Nacional da Serra do Cipó and Reserva Particular do Patrimônio Natural Serra do Caraça (Cordeiro Jr. \& Talamoni, 2006; Pessôa et al., 2015).

Major threats: the major threat to this species is continuing decline in the extent and quality of its habitat; also, there are frequent fires in its range.

Current conservation efforts: it is listed as EN in Brazil (Brasil, 2014) and included in the Minas Gerais List of Threatened Species in category VU (Minas Gerais, 2010). Trinomys moojeni is included in the Conservation Action
Planning of Central Atlantic Forest Mammals (EscarlateTavares et al., 2016). Trinomys moojeni occurs in two protected areas.

Trinomys yonenagae Rocha, 1996 - Yonenaga's

Atlantic Spiny Rat

IUCN Red List: EN B2ab(i,ii,iii) / Brazil: EN B1ab(ii,iii) / Bahia: EN.

Description: this species occurs in semiarid dune habitats in Caatinga biome of Brazil. It is known from middle Rio São Francisco in northwestern Bahia state where it lives a gregarious, semi-fossorial lifestyle in self-dug burrow systems (Santos \& Lacey, 2011; Pessôa et al., 2015).

Major threats: this species is threatened by habitat loss, especially due to commercial sand mining (Luchesi et al., 2019).

Current conservation efforts: it was recently included in the Bahia's List of Threatened Species in category EN (Cassano et al., 2017) and listed as EN in Brazil (Brasil, 2014).

\section{Erethizontidae}

Chaetomys subspinosus (Olfers, 1818) -

Bristle-spined Rat

IUCN Red List: VU B2ab(ii,iii,iv) / Brazil: VU B2ab(ii,iii) / Bahia: VU / Espírito Santo: VU.

Description: it is endemic to Brazil and occurs in fragments of Atlantic coastal plains and mountains, from Sergipe to northern Rio de Janeiro (Voss, 2011). This species is nocturnal and arboreal, and prefers habitat with high levels of vertical complexity (Barthelmess, 2016). Male individuals of this species utilize a range almost triple the size of their female counterparts (Giné et al., 2015).

Major threats: this species is threatened by deforestation, and many populations are now extinct from forest lost (Barthelmess, 2016). Less than $17 \%$ of previous forest cover remains within this species' current geographic range (Barthelmess, 2016).

Current conservation efforts: there are currently conservation efforts in action to protect this species, mainly 
undertaken by the group or researchers from the Graduate Program in Ecology and Biodiversity Conservation, State University of Santa Cruz, Bahia. Chaetomys subspinosus has a National Action Plan (Faria et al., 2011), is listed as VU in Brazil (Brasil, 2014) and included in the Bahia and Espírito Santo's List of Threatened Species in category VU (Cassano et al., 2017; Espírito Santo, 2005).

\section{Coendou speratus Mendes Pontes, Gadelha,} Melo de Sá Loss, Caldara Junior, Costa \&

Leite, 2013 - Pernambuco Dwarf Porcupine

IUCN Red List: EN B1ab(i,ii,iii,iv,v) + 2ab(i,ii,iii,iv,v) / Brazil: EN Blab(iii).

Description: this species is found in fragmented lowland evergreen forest habitat and remnant patches of sub montane Atlantic Forest in the states of Pernambuco and Alagoas in Brazil (Leal et al., 2017; Mendes Pontes et al., 2013). This species lives in dens in hollow trees and is likely nocturnal, as all observations have occurred at night (Mendes Pontes et al., 2013; Voss, 2011).

Major threats: it is found in forest fragments that face anthropogenic pressure in the form of logging, hunting, and general development. Remaining forest fragments are small and in poor condition (ICMBio, 2018).

Current conservation efforts: This species occurs in one protected area (Estação Ecológica Murici, Área de Proteção Ambiental Estadual de Murici, state of Alagoas); there are no existing conservation plans specific to it (ICMBio, 2018). It is listed as EN in Brazil (Brasil, 2014).

\section{DISCUSSION}

There were 20 species in one of the Threatened Categories out of the 194 actually assessed for this study (234 less 40 DD species), or $10.3 \%$. This is far less than the number of threatened species for mammals as a whole, which was 25\% in Schipper et al. (2008). This paper also speculated on the impact of species classified as DD on overall conservation status as a group. If all DD species were considered under no threat of extinction, adding them to the total would reduce the percent of rodents actually in an IUCN Category of threat, whereas if all were threatened then this would raise the percentage. There are currently 40 DD species of rodents, and using the same approach as Schipper et al. (2008) the percentage of threatened rodents could range from to $8.5 \%$ to $25.6 \%$, approaching the number for the class Mammalia. Most studies have shown that a relatively high percentage of DD species are at risk once sufficient data are obtained. Jetz \& Freckleton (2015) used a combination of phylogenetic and spatial models to predict threat data for 483 species of DD mammals. These models predicted that $69 \%$ of these species would have an elevated risk of extinction and that an estimated $21.5 \%$ of rodent species would be potentially in a Threatened Category. One of the highest priorities in the IUCN Red List Unit is to reduce the number of species currently assessed as DD. In many cases this can only be completed with additional field research, but using a combination of expert opinion coupled with modeling approaches (application of Criterion E) as above can also provide valid assessments.

Another concern is the very high percentage of LC species, $87 \%$ of those species assessed $(n=194)$. Although this could reflect the adaptability and tolerance of rodents, it could also reflect application of poor spatial data (in fact, the gaps on the distribution of samples are immense; see for instance, Prado \& Percequillo, 2013). Of all the species assessed as threatened or of concern, 21 used criterion B and one used D2 (Podoxymys roraimae). Only Cavia intermedia (D) had population data, because its distribution on a small oceanic island had allowed for a direct census (Salvador \& Fernandez, 2008). Assessments of Brazilian rodents are almost completely lacking in any kind of population data that would allow for an assessment of trends. The reliance on Criterion B, in particular EOO, can result in an overestimate of the dispersion of risk when there is use of historical point locality data. Many peripheral populations could have been exterminated and a failure to attempt to estimate available habitat can create a sense of complacency regarding the status of many species. A novel 
alternative approach, estimation of Area of Habitat $(\mathrm{AOH})$ is not equivalent to either $\mathrm{EOO}$ or $\mathrm{AOO}$, but can provide insights on refining survey and assessment methods that would yield better estimates of EOO or the development of an $\mathrm{AOO}$ given additional data collection (Brooks et al., 2019). More fieldwork will invariably improve assessments for both DD and LC species.

The break-down of threat and Data Deficiency shows that some families are of elevated concern. The percent of species of concern for the caviomorph family Echimyidae is $14.3 \%$ and the percent DD species is also high for Echimyidae (19\%) but also for Dasyproctidae (44.4\%). The sum of concern and DD for echimyids is $33.3 \%$. These two families need additional ecological, behavioral, and phylogenetic research and should be priorities for funding at the state and federal level. Although the family Ctenomyidae has low overall richness in Brazil, two-thirds of the species are either Threatened or Data Deficient. In addition to their unique morphological, behavioral, and ecological characteristics, they provide valuable ecosystem function roles in aerating and mixing soils. Most species also have very restricted ranges and merit a stronger conservation focus.

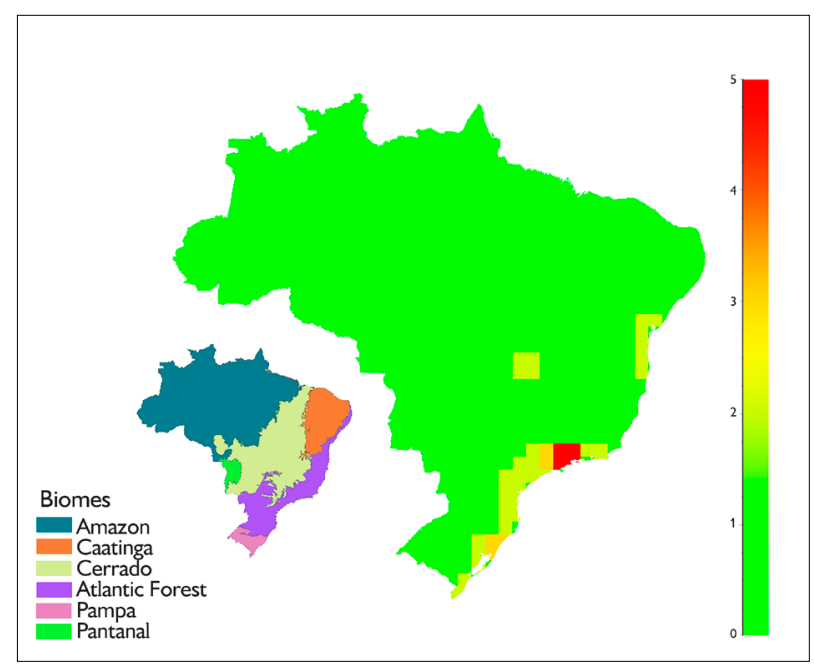

Figure 3. A heat map of the density of species of conservation concern, highlighting the Atlantic Forest and parts of the Cerrado. Map: crested by authors, insert of biomes modified from from https://data.globalforestwatch.org/datasets/54ec099791644be4b2 $73 d 9 d 8 a 853 d 4524$
In addition to the patterns for family there were also strong spatial patterns for both species of concern and DD species, as revealed in the heat maps (Figures 3 and 4) and the distribution of the 24 species of concern (Table 3). The Atlantic Forest is clearly the highest priority for the implementation of conservation action. It is the most important region for a high concentration of threatened species, followed by the Cerrado. The Atlantic Forest and Cerrado also harbor high densities of DD species, as does the Amazon, in particular the eastern Amazonian Basin. There has been significant prior emphasis on the conservation of Atlantic Forest mammals (Galetti et al., 2009) and habitats (Tabarelli et al., 2010), but clearly the need remains high.

Given the increasing threats to biodiversity of habitat alteration, climate change, invasive species, and diseases, we would expect a convergence of efforts among institutions and agencies to unite research and conservation policy and action in the most efficient manner possible. Unfortunately, there remains a disconnect in the research and conservation rewards and priorities especially between academic institutions and conservation agencies and organizations. These represent

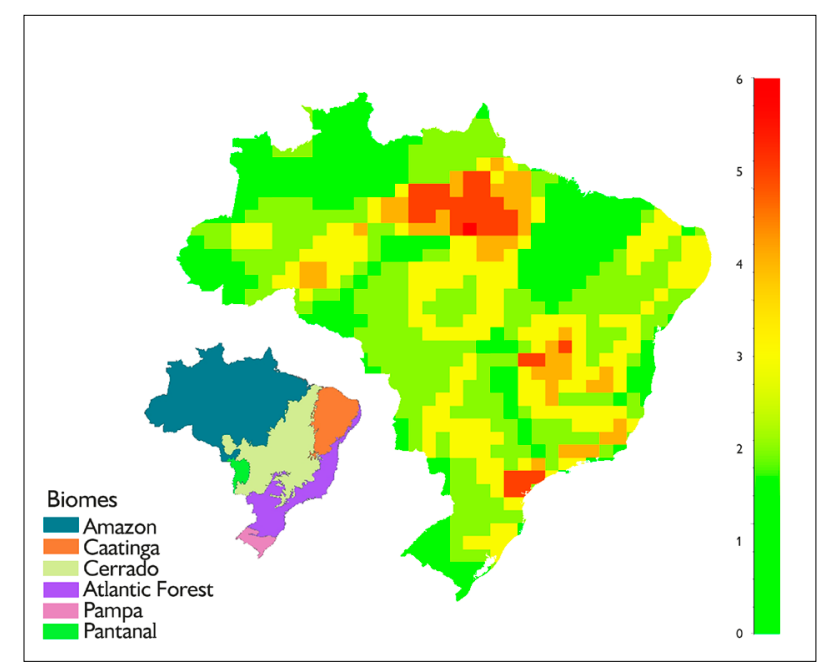

Figure 4. A heat map of the density of Data Deficient species, highlighting the Atlantic Forest, the Cerrado, and the eastern Amazon. Map: crested by authors, insert of biomes modified from from https://data.globalforestwatch.org/datasets/54ec099791644b e4b273d9d8a853d452 4

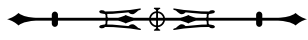


natural partners, where universities gather and prioritize research data that can best address our biodiversity crisis. Better collaborations between universities and conservation NGOs are urgent to improve our knowledge of DD and LC species (Lacher et al., 2012) and the implementation of conservation actions (Hoffmann et al., 2010), where we can clearly demonstrate conservation successes.

\section{ACKNOWLEDGEMENTS}

We thank Texas A\&M University for logistical assistance and student financial support (specifically to N. Roach, S. McCay, and L. Wolf), the IUCN Red List Unit, Cambridge, UK for permission to use figures one and two, and to all of the Latin American and US assessors who contributed to the New World Red List assessment process for the IUCN SSC Small Mammal Specialist Group. Also, to M. Miretzki for his help in obtaining Brazilian scientific literature not available on the web. Two anonymous reviewers for valuable suggestions and comments in a previous version of this manuscript.

\section{REFERENCES}

ABREU-JR., E. F., D. M. CASALI, G. S. T. GARBINO, D. LORETTO, A. C. LOSS, M. MARMONTEL, M. C. NASCIMENTO, M. L. OLIVEIRA, S. E. PAVAN \& F. P. TIRELLI, 2020. Lista de Mamíferos do Brasil. Comitê de Taxonomia da Sociedade Brasileira de Mastozoologia (CT-SBMz). Available in: https://www.sbmz.org/ mamiferos-do-brasil/. Accessed on: 15 October 2020.

ASQUITH, N. M., J. TERBORGH, JR., A. E. ARNOLD, N. RIVEROS \& N. CAROLINA, 1999. The fruits the agouti ate: Hymenaea courbari seed fate when its disperser is absent. Journal of Tropical Ecology 15(2): 229-235. DOI: https://doi.org/10.1017/S0266467499000772

BARTHELMESS, E. L., 2016. Family Erethizontidae. In: D. E. WILSON, T. E. LACHERJR. \& R. A. MITTERMEIER (Ed.): Handbook of Mammals of the World: vol. 6: Lagomorphs and Rodents: Part 1: 372-397. Lynx Editions, Barcelona, Spain.

BERGALLO, H. G., C. F. D. ROCHA, M. A. S. ALVES \& M. VAN SLUYS, 2000. A fauna ameaçada de extinção do Estado do Rio de Janeiro: 1. ed.: 1-819. Editora da Universidade do Estado do Rio de Janeiro, Rio de Janeiro.

BERGALLO, H. G. \& A. PERCEQUILLO, 2019. Rhagomys rufescens. The IUCN Red List of Threatened Species 2019: e.T19454A22353755. DOI: http://dx.doi.org/10.2305/IUCN. UK.2019-1.RLTS.T19454A22353755.en
BIDAU, C. J., 2015. Family Ctenomyidae. In: J. L. PATTON, U. F. J. PARDIÑAS \& G. D'ELÍA (Ed.): Mammals of South America: vol. 2: Rodents: 818-877. University of Chicago Press, Chicago and London.

BONVICINO, C. R., B. LEMOS \& M. WEKSLER, 2005. Small mammals of Chapada dos Veadeiros National Park (Cerrado of Central Brazil): ecologic, karyologic, and taxonomic considerations. Brazilian Journal of Biology 65(3): 395-406. DOI: https://doi. org/10.1590/s1519-69842005000300004

BONVICINO, C. \& L. GEISE, 2008. Juliomys rimofrons. In: INTERNATIONAL UNION FOR CONSERVATION OF NATURE AND NATURAL RESOURCES (IUCN): IUCN Red List of Threatened Species. Version 2012.1. Available at: www.iucnredlist. org. Accessed on: July 2012.

BOVENDORP, R. S., F. T. BRUM, R. A. MCCLEERY, B. BAISER, R. LOYOLA, M. V. CIANCIARUSO \& M. GALETTI, 2019. Defaunation and fragmentation erode small mammal diversity dimensions in tropical forest. Ecography 42(1): 23-35. DOI: https://doi.org/10.1111/ ecog.03504

BRANDÃO, M. V., 2015. The presence of Wilfredomys oenax (Rodentia: Cricetidae: Sigmodontinae) in São Paulo state, southeastern Brazil: a locally extinct species? Papéis Avulsos de Zoologia 55(4): 69-80. DOI: http://dx.doi.org/10.1590/00311049.2015.55.04

BRASIL, 1968. Instituto Brasileiro de Desenvolvimento Florestal - IBDF. Portaria n 303, de 29 de maio de 1968. Diário Oficial da União.

BRASIL, 1973. Instituto Brasileiro de Desenvolvimento Florestal IBDF. Portaria n 3481-DN/1973. Diário Oficial da União.

BRASIL, 1989. Portaria IBAMA n 1522/1989. Dispõe sobre a Lista Oficial de Espécies da Fauna Brasileira Ameaçada de Extinção. Diário Oficial da União. Available at: https://cetesb.sp.gov.br/ licenciamento/documentos/1989 Port IBAMA 1522.pdf. Accessed on: 6 December 2019.

BRASIL, 2003. Ministério do Meio Ambiente. Instrução normativa $n^{\circ} 003$, de 26 de maio de 2003. Diário Oficial da União. Available at: https://www.icmbio.gov.br/portal/images/stories/biodiversidade/ fauna-brasileira/normativas/IN\%2003-2003\%20Fauna.pdf. Accessed on: 6 December 2019.

BRASIL, 2014. Ministério do Meio Ambiente. Portaria MMA n 444, de 17 de dezembro de 2014. Diário Oficial da União. Available at: https://www.icmbio.gov.br/portal/images/stories/ docs-plano-de-acao-ARQUIVO/00-saiba-mais/04 - PORTARIA MMA_N\%C2\%BA 444_DE_17_DE_DEZ_DE_2014.pdf. Accessed on: 6 December $2 \overline{0} 19$.

BRENNAND, P. G. G., A. LANGGUTH \& A. R. PERCEQUILLO, 2013. The genus Hylaeamys Weksler, Percequillo, and Voss 2006 (Rodentia: Cricetidae, Sigmodontinae) in the Brazilian Atlantic Forest: geographic variation and species definition. Journal of Mammalogy 94(6): 1346-1363. DOI: https://doi.org/10.1644/12-MAMM-A-312.1

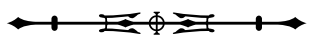


BRITO, D. \& M. S. L. FIGUEIREDO, 2003. Minimum viable population and conservation status of the Atlantic Forest spiny rat Trinomys eliasi. Biological Conservation 113(1): 153-158. DOI: https://doi.org/10.1016/S0006-3207(02)00344-0

BROOKS, T. M., S. L. PIMM, H. R. AKÇAKAYA, G. M. BUCHANAN, S. H. M. BUTCHART, W. FODEN, C. HILTON-TAYLOR, M. HOFFMANN, C. N. JENKINS, L. JOPPA, B. V. LI, V. MENON, N. OCAMPO-PEÑUELA \& C. RONDININI, 2019. Measuring terrestrial area of habitat $(\mathrm{AOH})$ and its utility for the IUCN Red List. Trends in Ecology and Evolution 34(11): 977-986. DOI: https:// doi.org/10.1016/j.tree.2019.06.009

BURGIN, C. J., J. P. COLELLA, P. I. KAHN \& N. S. UPHAM, 2018. How many species of mammals are there? Journal of Mammalogy 99(1): 1-14. DOI: https://doi.org/10.1093/jmammal/gyx147

BUTCHART, S. H. M., A. J. STATTERSFIELD, J. BAILLIE, L. A. BENNUM, S. N. STUART, H. RAKÇAKAYA, C. HILTON-TAYLOR \& G. M. MACE, 2005. Using Red List Indices to measure progress towards the 2010 target and beyond. Philosophical Transaction of the Royal Society B 360(1454): 255-268. DOI: https://doi. org/10.1098/rstb.2004.1583

CARVALHO, J. C. M., 1968. Lista das espécies de animais e plantas ameaçadas de extinção no Brasil. Boletim Informativo, Fundação Brasileira para a Conservação da Natureza-FBCN 3: 11-16.

CASSANO, C. R., J. M. ALMEIDA-ROCHA, C. S. S. BERNARDO, G. V. BIANCONI \& J. E. I. XIMENES, 2017. Primeira avaliação do status de conservação dos mamíferos do estado da Bahia, Brasil. Oecologia Australis 21(2): 156-170. DOI: https://doi.org/10.4257/ oeco.2017.2102.06

CHIQUito, E. A., G. D'ElÍA \& A. R. PERCEQUILLO, 2014. Taxonomic review of genus Sooretamys Weksler, Percequillo \& Voss (Rodentia: Cricetidae: Sigmodontinae): an integrative approach. Zoological Journal of the Linnean Society 171(4): 842-877. DOI: https://doi.org/10.1111/zoj.12146

CHIQUITO, E. A. \& A. R. PERCEQUILLO, 2019. The taxonomic status of Nectomys saturatus Thomas, 1897 (Cricetidae: Sigmodontinae). Zootaxa 4550(3): 321-339. DOI: https://doi. org/10.11646/zootaxa.4550.3.2

COIMBRA-FILHO, A. F., 1972. Mamíferos ameaçados de extinção no Brasil. In: ACADEMIA BRASILEIRA DE CIÊNCIAS (ABC) (Ed.): Espécies da fauna brasileira ameaçados de extinção: 13-98. Ed. Academia Brasileira de Ciências, Rio de Janeiro.

COIMBRA-FILHO, A. F. \& A. MAGNANINI, 1968. Animais raros ou em vias de desaparecimento no Brasil. Anuário Brasileiro de Economia Florestal 19(9): 148-177.

CORDEIRO JR., D. A. \& S. A. TALAMONI, 2006. New data on the life history and occurrence of spiny rats Trinomys moojeni (Rodentia: Echimyidae), in southeastern Brazil. Acta Theriologica 51(2): 163-68. DOI: https://doi.org/10.1007/BF03192667
DELCIELLOS, A. C., M. AGUIEIRAS, L. GEISE, M. WEKSLER \& O. ROCHA-BARBOS, 2015. First record of Drymoreomys albimaculatus Percequillo, Weksler \& Costa, 2011 (Rodentia, Cricetidae, Sigmodontinae) in Rio de Janeiro state, Brazil. Check List 11(2): 1-5. DOI: http://dx.doi.org/10.15560/11.2.1572

DIRZO, R., H. S. YOUNG, M. GALETTI, G. CEBALLOS, N. J. B. ISAAC \& B. COLLEN, 2014. Defaunation in the Anthropocene. Science 345(6195): 401-406. DOI: https://doi.org/10.1126/ science. 1251817

EISENBERG, J. F. \& K. H. REDFORD, 1999. Mammals of the Neotropics. The Central Neotropics: vol. 3: 1-624. The University of Chicago Press, Chicago, USA.

EMMONS, L. H., Y. L. R. LEITE, D. KOCK \& L. P. COSTA, 2002. A review of the named forms of Phyllomys (Rodentia: Echimyidae) with the description of a new species from coastal Brazil. American Museum Novitates 3380: 1-40. DOI: https:// doi.org/10.1206/0003-0082(2002)380\%3C0001:AROTNF\%3 E2.0.CO;2

EMMONS, L. H., Y. L. R. LEITE \& J. L. PATTON, 2015. Genus Callistomys Emmons and Vucetich, 1988. In: J. L. PATTON, U. F. J. PARDIÑAS \& G. D'ELÍA (Ed.): Mammals of South America: vol. 2: Rodents: 889-890. University of Chicago Press, Chicago and London.

ENGELBREKTSSON, P., 2019. Drymoreomys albimaculatus. The IUCN Red List of Threatened Species 2019: e.T46205572A46207033. DOI: http://dx.doi.org/10.2305/IUCN. UK.2019-1.RLTS.T46205572A46207033.en

ESCARLATE-TAVARES, F., M. M. VALENÇA-MONTENEGRO \& L. JERUSALINSKY, 2016. Plano de Ação Nacional dos Mamíferos da Mata Atlântica Central: 1 ed.: 1-353. ICMBio (Série Espécies Ameaçadas, 23), Brasília.

ESPÍRITO SANTO (GOVERNO DO ESTADO), 2005. Decreto $n^{\circ} 1499-R$ de 13 de junho de 2005. Declara as espécies da Fauna e Flora silvestres ameaçadas de extinção no Estado do Espírito Santo, e dá outras providências. Diário Oficial. Available at: https://docplayer.com.br/143066188-Decreto-no-1499-r-de-13de-junho-de-2005.html. Accessed on: 6 December 2019.

FABRE, P. H., J. L. PATTON \& Y. L. R. LEITE, 2016. Family Echimyidae. In: D. E. WILSON, T. E. LACHER JR. \& R. A. MITTERMEIER (Ed.): Handbook of Mammals of the World: vol. 6: Lagomorphs and Rodents: 552-634. I. Lynx Editions, Barcelona, Spain.

FARIA, D., G. A. F. GINÉ \& M. L. REIS, 2011. Plano de ação nacional para conservação do ouriço preto: 1-66. ICMBio, Brasília.

FONSECA, R., H. G. BERGALLO, A. C. DELCIELLOS, O. ROCHABARBOSA \& L. GEISE, 2013. Juliomys rimofrons Oliveira \& Bonvicino, 2002 (Rodentia: Cricetidae): Distribution extension. Check List 9(3): 684-685. DOI: https://doi.org/10.15560/9.3.684

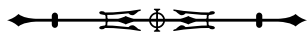


FREITAS, T. R. O., 1995. Geographic distribution and conservation of four species of the genus Ctenomys in southern Brazil. Studies on Neotropical Fauna and Environment 30(1): 53-59. DOI: https:// doi.org/10.1080/01650529509360941

GALETTI, M., H. C. GIACOMINI, R. S. BUENO, C. S. S. BERNARDO, R. M. MARQUES, R. S. BOVENDORP, C. E. STEFFLER, P. RUBIM, S. K. GOBBO, C. I. DONATTI, R. A. BEGOTTI, F. MEIRELLES, R. A. NOBRE, A. G. CHIARELLO \& C. A. PERES, 2009. Priority areas for the conservation of Atlantic forest large mammals. Biological Conservation 142(6): 1229-1241. DOI: https://doi.org/10.1016/j.biocon.2009.01.023

GALETTI, M., R. GUEVARA, M. C. CÔRTES, R. FADINI, S. VON MATTER, A. B. LEITE, F. LABECCA, T. RIBEIRO, C. S. CARVALHO, R. G. COLLEVATTI, M. M. PIRES, P. R. GUIMARÃES, P. H. BRANCALION, M. C. RIBEIRO \& P. JORDANO, 2013. Functional extinction of birds drives rapid evolutionary changes in seed size. Science 340(6136): 1086-1090. DOI: https://doi. org/10.1126/science. 1233774

GAVA, A. \& T. R. O. FREITAS, 2003. Inter and intra-specific hybridization in Tuco-Tucos (Ctenomys) from Brazilian Coastal Plains (Rodentia: Ctenomyidae). Genetica 119(1): 11-17. DOI: https://doi. org/10.1023/A:1024465429856

GINÉ, G. A. F., J. M. B. DUARTE \& D. FARIA, 2015. Home range and multiscale habitat selection of threatened Thin-Spined Porcupine in the Brazilian Atlantic Forest. Journal of Mammology 96(5): 1095-1105. DOI: https://doi.org/10.1093/jmammal/gyv117

HOFFMANN, M., C. HILTON-TAYLOR, A. ANGULO et al. 2010. The impact and shortfall of conservation on the status of the world's vertebrates. Science 330(6010): 1503-1509. DOI: https:// doi.org/10.1126/science.1194442

INSTITUTO CHICO MENDES DE CONSERVAÇÃO DA BIODIVERSIDADE (ICMBio), 2018. Livro vermelho da fauna brasileira ameaçada de extinção: vol. 2: Mamíferos: 1-622. ICMBio, Brasília.

INTERNATIONAL UNION FOR CONSERVATION OF NATURE AND NATURAL RESOURCES (IUCN), 2001. IUCN Red List Categories and Criteria: version 3.1: 1-30. IUCN Species Survival Commission. IUCN, Gland, Switzerland and Cambridge, UK. Available at: https://portals.iucn.org/library/sites/library/files/ documents/RL-2001-001.pdf. Accessed on: 6 December 2019.

INTERNATIONAL UNION FOR CONSERVATION OF NATURE AND NATURAL RESOURCES (IUCN), 2020a. IUCN Red List Categories and Criteria. Available at: https://www.iucnredlist.org/ resources/categories-and-criteria. Accessed on: 6 December 2019.

INTERNATIONAL UNION FOR CONSERVATION OF NATURE AND NATURAL RESOURCES (IUCN), 2020b. The IUCN Red List of Threatened Species. Version 2020-2. Available at: https:// www.iucnredlist.org/. Accessed on: 6 December 2019.
INTERNATIONAL UNION FOR CONSERVATION OF NATURE AND NATURAL RESOURCES (IUCN), 2020c. Contact Details. Available at: https://www.iucnredlist.org/contact/contact-page. Accessed on: 6 December 2019.

INTERNATIONAL UNION FOR CONSERVATION OF NATURE AND NATURAL RESOURCES (IUCN), [n. d.a]. The IUCN Global Species Programme. Available at: https://www.iucn.org/theme/ species/about/iucn-global-species-programme. Accessed on: 6 December 2019.

INTERNATIONAL UNION FOR CONSERVATION OF NATURE AND NATURAL RESOURCES (IUCN), [n. d.b]. Species Survival Commission. Available at: https://www.iucn.org/species/about/ species-survival-commission. Accessed on: 6 December 2019.

JETZ, W. \& R. P. FRECKLETON, 2015. Towards a general framework for predicting threat status of data-deficient species from phylogenetic, spatial and environmental information. Philosophical Transactions of the Royal Society 370(1662): 20140016. DOI: https://doi. org/10.1098/rstb.2014.0016

KEESING, F., 2000. Cryptic consumers and the ecology of an African Savanna. BioScience 50(3): 205-215. DOI: https://doi. org/10.1641/0006-3568(2000)050[0205:CCATEO]2.3.CO;2

LACHER, T. E., JR., L. BOITANI \& G. A. B. FONSECA, 2012. The IUCN Global Assessments: Partnerships, collaboration and data sharing for biodiversity science and policy. Conservation Letters 5(2012): 327-333. DOI: https://doi.org/10.1111/j.1755$263 \times .2012 .00249 . x$

LACHER, T. E., JR., 2016. Family Caviidae. In: D. E. WILSON, T. E. LACHER JR. \& R. A. MITTERMEIER (Ed.): Handbook of Mammals of the World: vol. 6: Lagomorphs and Rodents: Part 1: 406-438. Lynx Editions, Barcelona, Spain.

LACHER, T. E., JR., R. P. YOUNG, R. KENNERLEY, N. S. ROACH, S. MCCAY \& S. T. TURVEY, 2016. Evolution, phylogeny, ecology, and conservation of the Clade Glires: Lagomorpha and Rodentia. In: D. E. WILSON, T. E. LACHER JR. \& R. A. MITTERMEIER (Ed.): Handbook of Mammals of the World: vol. 6: Lagomorphs and Rodents: 28-60. Lynx Editions, Barcelona, Spain.

LEAL, B., E. S. GOMES-SILVA, F. F. LYRA-NEVES, R. M. DE TELINO-JÚNIOR \& R. WALLACE, 2017. Range extension and first record of Coendou speratus Mendes Pontes et al., 2013 (Rodentia, Erethizontidae) from a cloud forest enclave in northeastern Brazil. Check List 13(6): 951-957. DOI: http://dx.doi.org/10.15560/13.6.951

LEITE, Y. L. R., 2003. Evolution and systematics of the Atlantic tree rats, genus Phyllomys (Rodentia, Echimyidae), with description of two new species: 1-137. University of California Press (UC Publications in Zoology, 132), Berkeley.

LEITE, Y. L. R. \& A. C. LOSS, 2015. Genus Phyllomys Lund, 1839. In: J. L. PATTON, U. F. J. PARIDAS \& G. D'ELÍA (Ed.): Mammals of South America: vol. 2: Rodents: 915-928. University of Chicago Press, Chicago and London.

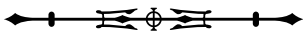


LINARES, O. J., 1998. Mamíferos de Venezuela: 1. ed.: 1-691: Sociedad Conservacionista Audubon de Venezuela, Caracas, Venezuela.

LOSS, C. \& Y. LEITE, 2016a. Phyllomys mantiqueirensis. The IUCN Red List of Threatened Species 2016: e.T136274A22210858. DOI: http:// dx.doi.org/10.2305/IUCN.UK.2016-2.RLTS.T136274A22210858.en

LOSS, C. \& Y. LEITE, 2016b. Phyllomys unicolor. The IUCN Red List of Threatened Species 2016: e.T6990A22210643. DOI: http:// dx.doi.org/10.2305/IUCN.UK.2016-3.RLTS.T6990A22210643.en

LUCHESI, L. C., L. M. R. CANTANO, J. T. TAKATA \& P. M. MONTICELLI, 2019. Trinomys yonenagae (Rodentia: Echimyidae). Mammalian Species 51(971): 1-10. DOI: https://doi.org/10.1093/ mspecies/sez001

MACHADO, A. B. M., 2008. Listas de espécies da fauna brasileira ameaçadas de extinção: aspectos históricos e comparativos. In: A. B. M. MACHADO, G. M. DRUMMOND \& A. P. PAGLIA (Ed.): Livro vermelho da fauna brasileira ameaçada de extinção: 1. ed.: 91-110. MMA/Fundação Biodiversitas, Brasilia/Belo Horizonte.

MENDES PONTES, A. R. M., J. R. GARDELHA, E. R. A. MELO, F. B. SÁ, A. C. LOSS, V. C. CALDARA JR., L. P. COSTA \& Y. L. R. LEITE, 2013. A new species of porcupine, genus Coendou (Rodentia: Erethizontidae) from the Atlantic forest of northeastern Brazil. Zootaxa 3636(3): 421-438. DOI: https://doi.org/10.11646/zootaxa.3636.3.2

MINAS GERAIS (GOVERNO DO ESTADO), 2010. Deliberação normativa COPAM no 147, de 30 de abril de 2010. Aprova a Lista de Espécies Ameaçadas de Extinção da Fauna do Estado de Minas Gerais. Diário do Executivo - "Minas Gerais”. Available at: http:// www.siam.mg.gov.br/sla/download.pdf?idNorma=13192. Accessed on: 6 December 2019.

MITTERMEIER, R. J., G. A. B. FONSECA, A. B. RYLANDS \& K. BRANDON, 2005. Uma breve história da conservação da biodiversidade no Brasil. Megadiversidade 1(1): 14-21.

MUSSER, G. G. \& M. D. CARLETON, 2005. Superfamily Muroidea. In: D. E. WILSON \& D. A. REEDER (Ed.): Mammal Species of the World: a geographic and taxonomic reference: 894-1531. The John Hopkins University Press, Baltimore, USA.

NAYLOR, L. \& N. ROACH, 2019. Juliomys rimofrons. The IUCN Red List of Threatened Species 2019: e.T136563A22330610. DOI: http:// dx.doi.org/10.2305/IUCN.UK.2019-1.RLTS.T136563A22330610.en

NOWAK, R. M., 1999. Walker's mammals of the world: v. 2, 6th: 837-2015. Johns Hopkins University Press, Baltimore, MD.

PAGLIA, A. P., G. A. B. FONSECA, A. B. RYLANDS, G. HERRMANN, L. M. S. AGUIAR, A. G. CHIARELLO, Y. L. R. LEITE, L. P. COSTA, S. SICILIANO, M. C. M. KIERULFF, S. L. MENDES, V. C. TAVARES, R. A. MITTERMEIER \& J. L. PATTON, 2012. Lista anotada dos mamíferos do Brasil/Annotated checklist of Brazilian mammals: 2. ed.: 1-76. Conservation International (Occasional Papers in Conservation Biology, 6), Arlington, VA.
PARANÁ (GOVERNO DO ESTADO), 2010. Decreto Estadual nº 7264/ 2010 - Reconhece e atualiza Lista de Espécies de Mamíferos pertencentes à Fauna Silvestre Ameaçadas de Extinção no Estado do Paraná e dá outras providências, atendendo o Decreto n 3148 , de 2004. Diário Oficial do Estado do Paraná.

PARESQUE, R. \& J. D. HANSON, 2015. Genus Microakodontomys Hershkovitz, 1993. In: J. L. PATTON, U. F. J. PARDIÑAS \& G. D'ELIA (Ed.): Mammals of South America: vol. 2: Rodents: 354- 355. The University of Chicago Press, Chicago, London.

PASSAMANI, M., R. A. S. CERBONCINI \& J. E. OLIVEIRA, 2011. Distribution extension of Phaenomys ferrugineus (Thomas, 1894), and new data on Abrawayaomys ruschii Cunha and Cruz, 1979 and Rhagomys rufescens (Thomas, 1886), three rare species of rodents (Rodentia: Cricetidae) in Minas Gerais, Brazil. Check List 7(6): 827 831. DOI: https://doi.org/10.15560/7.6.827

PATTON, J., 2018. Podoxymys roraimae. The IUCN Red List of Threatened Species 2018: e.T17831A22390812. DOI: http:// dx.doi.org/10.2305/IUCN.UK.2018-1.RLTS.T17831A22390812.en

PATTON, J. L., U. F. J. PARDIÑAS \& G. D'ELÍA, 2015. Mammals of South America: vol. 2: Rodents: 1-1384. The University of Chicago Press, Chicago.

PERCEQUILLO, A., 2015a. Genus Euryoryzomys Weksler, Percequillo, and Voss, 2006. In: J. L. PATTON, U. F. J. PARDIÑAS \& G. D'ELÍA (Ed.): Mammals of South America: vol. 2: Rodents: 312-321. University of Chicago Press, Chicago and London.

PERCEQUILLO, A., 2015b. Genus Hylaeamys Weksler, Percequillo, and Voss, 2006. In: J. L. PATTON, U. F. J. PARDIÑAS \& G. D'ELÍA (Ed.): Mammals of South America: vol. 2: Rodents: 335-346. University of Chicago Press, Chicago and London.

PERCEQUILLO, A., 2015c. Genus Phaenomys Weksler, Percequillo, and Voss, 2006. In: J. L. PATTON, U. F. J. PARDIÑAS \& G. D'ELÍA (Ed.): Mammals of South America: vol. 2: Rodents: 101-103. University of Chicago Press, Chicago and London.

PERCEQUiLLO, A. R., M. WEKSLER \& L. P. COSTA, 2011. A new genus and species of rodent from the Brazilian Atlantic Forest (Rodentia: Cricetidae: Sigmodontinae: Oryzomyini), with comments on oryzomyine biogeography. Zoological Journal of the Linnean Society 161(2): 357-390. DOI: https://doi.org/10.1111/j.10963642.2010.00643.x

PERCEQUILLO, A. R. \& M. WEKSLER, 2015. Genus Drymoreomys Percequillo, Weksler, and Costa, 2011. In: J. L. PATTON, U. F. J. PARDIÑAS \& G. D'ELÍA (Ed.): Mammals of South America: vol. 2: Rodents: 308-310. University of Chicago Press, Chicago and London.

PERCEQUILLO, A. R., J. DALAPICOLLA, E. F. ABREU-JÚNIOR, P. R. O. ROTH, I. M. P. M. B. FERRAZ \& E. A. CHIQUITO, 2017. How many species of mammals are there in Brazil? New records of rare rodents (Rodentia: Cricetidae: Sigmodontinae) from Amazonia raise the current known diversity. Peerj 5: e4071. DOI: https://doi. org/10.7717/peerj.4071

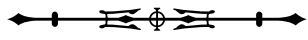


PERCEQUILLO, A. \& N. ROACH, 2017. Hylaeamys oniscus. The IUCN Red List of Threatened Species 2017: e. T15608A22327982. DOI: http://dx.doi.org/10.2305/IUCN.UK.2017-2.RLTS. T15608A22327982.en

PERCEQUILLO, A. R. \& M. WEKSLER, 2018. Euryoryzomys lamia. The IUCN Red List of Threatened Species 2018: e.T15602A739675. DOI: https://dx.doi.org/10.2305/IUCN. UK.2018-2.RLTS.T15602A739675.en

PERCEQUILLO, A. R. \& M. WEKSLER, 2019. Hylaeamys laticeps. The IUCN Red List of Threatened Species 2019: e.T29404A22327572. DOI: https://dx.doi.org/10.2305/IUCN. UK.2019-3.RLTS.T29404A22327572.en

PERES, C. A., T. EMILIO, J. SCHIETTI, S. J. M. DESMOULIÈRE \& T. LEVI, 2016. Dispersal limitation induces long-term biomass collapse in overhunted Amazonian forests. Proceedings of the National Academy of Sciences of the United States of America 113(4): 892-897. DOI: https://doi.org/10.1073/pnas.1516525113

PESSÔA, L. M., W. C. TAVARES, J. A. DE OLIVEIRA \&. L. PATTON, 2015. Genus Trinomys Thomas, 1921. In: J. L. PATTON, U. F. J. PARDIÑAS \& G. D'ELIA (Ed.): Mammals of South America: vol. 2: Rodents: 999-1017. The University of Chicago Press, Chicago, London.

PRADO, J. R. \& A. R. PERCEQUILLO, 2013. Geographic distribution of the genera of the Tribe Oryzomyini (Rodentia: Cricetidae: Sigmodontinae) in South America: patterns of distribution and diversity. Arquivos de Zoologia 44(1): 1-120. DOI: https://doi. org/10.11606/issn.2176-7793.v44i1p1-120

RIO GRANDE DO SUL, 2014. Decreto n. ${ }^{\circ}$ 51.797, de 8 de setembro de 2014. Declara as espécies da fauna silvestre ameaçadas de extinção no estado do Rio Grande do Sul. Diário Oficial. Available at: http://www.al.rs.gov.br/filerepository/replegis/arquivos/dec\%20 51.797.pdf. Accessed on: 6 December 2019.

ROACH, N., 2016. Cavia intermedia. The IUCN Red List of Threatened Species 2016: e.T136520A22189125. DOI: http:// dx.doi.org/10.2305/IUCN.UK.2016-2.RLTS.T136520A22189125.en

ROACH, N. \& L. NAYLOR, 2016. Trinomys moojeni. The IUCN Red List of Threatened Species 2016: e.T136543A22211597. DOI: http:// dx.doi.org/10.2305/IUCN.UK.2016-2.RLTS.T136543A22211597.en

SAATCHI, S., D. AGOSTI, K. ALGER, J. DELABIE \& J. MUSINSKY, 2001. Examining fragmentation and loss of primary forest in the southern Bahian Atlantic Forest of Brazil with radar imagery. Conservation Biology 15(4): 867-875.

SALVADOR, C. H. \& F. A. S. FERNANDEZ, 2008. Population dynamics and conservation status of the insular cavy Cavia intermedia (Rodentia: Caviidae). Journal of Mammalogy 89(3): 721-729. DOI: https://doi.org/10.1644/07-MAMM-A-0088R1.1

SAMUELS, J. X., 2009. Cranial morphology and dietary habits of rodents. Zoological Journal of the Linnean Society 156(4): 864888. DOI: https://doi.org/10.1111/J.1096-3642.2009.00502.x
SANTA CATARINA (GOVERNO DO ESTADO), 2019. Portaria no $236 / 2019$ - IMA de 12/11/2019. Available at: https://www.ima. sc.gov.br/index.php/biodiversidade/planos-de-acao/pae-prea-demoleques. Accessed on: 6 December 2019.

SANTOS, J. W. A. \& E. A. LACEY, 2011. Burrow sharing in the desert-adapted torch-tail spiny rat, Trinomys yonenagae. Journal of Mammalogy 92(1): 3-11. DOI: https://doi.org/10.1644/09MAMM-S-389.1

SÃO PAULO (GOVERNO DO ESTADO), 2011. Deliberação CONSEMA Normativa 02/2011. Dispõe sobre a elaboração e a atualização de lista de espécies exóticas com potencial de bioinvasão no Estado de São Paulo e dá outras providências. Diário Oficial. Available at: https://smastr16.blob.core.windows.net/consema/deliberacoes/2011/ DelNormativa02.pdf. Accessed on: 6 December 2019.

SÃO PAULO (GOVERNO DO ESTADO), 2018. Decreto n 63.853, de 27 de novembro de 2018. Declara as espécies da fauna silvestre no Estado de São Paulo regionalmente extintas, as ameaçadas de extinção, as quase ameaçadas e as com dados insuficientes para avaliação, e dá providências correlatas. Diário Oficial. Available at: https://www.al.sp.gov.br/repositorio/legislacao/decreto/2018/ decreto-63853-27.11.2018.html. Accessed on: 6 December 2019.

SCHIPPER, J., J. S. CHANSON, F. CHIOZZA, N. A. COX, M. HOFFMANN et al. 2008. The status of the world's land and marine mammals: diversity, threat, and knowledge. Science 322(5899): 225-230. DOI: https://doi.org/10.1126/science.1165115

SCOTT, S. P., J. A. BURTON \& R. FITTER, 1987. Red Data Books: the historical background. In: R. FITTER \& M. FITTER (Ed.): The road to extinction: problems of categorizing the status of taxa threatened with extinction: 1-7. IUCN Gland, Switzerland and Cambridge, UK.

SOUZA, E. C. F., A. BRANT, C. A. RANGEL, E. BARBOSA, C. E. G. CARVALHO, R. S. P. JORGE \& R. J. SUBIRÁ, 2018. Avaliação do risco de extinção da fauna brasileira: ponto de partida para a conservação da biodiversidade. Diversidade e Gestão 2(2): 62-75.

SPECIES INFORMATION SERVICE (SIS), [n. d.]. Available at: https:// sis.iucnsis.org/apps/org.iucn.sis.server/SIS/index.html. Accessed on: 6 December 2019.

TABARELLI, M., A. V. AGUIAR, M. C. RIBEIRO, J. P. METZGER \& C. A. PERES, 2010. Prospects for biodiversity conservation in the Atlantic Forest: lesson from aging human-modified landscapes. Biological Conservation 143(10): 2328-2340. DOI: https://doi. org/10.1016/j.biocon.2010.02.005

THE NATURE CONSERVANCY, 2019. Available at: https://www. conservationtraining.org/. Accessed on: 6 December 2019.

VIÉ, J.-C., C. HILTON-TAYLOR, C. POLLOCK, J. RAGLE, J. SMART, S. STUART \& R. TONG, 2008. The IUCN Red List: a key conservation tool. In: J.-C. VIÉ, C. HILTON-TAYLOR \& S. N. STUART (Ed.): The 2008 Review of the IUCN Red List of Threatened Species: 1-13. IUCN Gland, Switzerland.

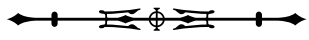


VOSS, R. S., 2011. Revisionary notes on Neotropical porcupines (Rodentia, Erethizontidae). 3. An annotated checklist of the species of Coendou Lacépède, 1799. American Museum Novitates 3720: 1-36. DOI: https://doi.org/10.1206/3720.2

WEKSLER, M., L. GEISE \& R. CERQUEIRA, 1999. A new species of Oryzomys (Rodentia, Sigmodontinae) from southeast Brazil, with comments on the classification of the $O$. capito species group. Zoological Journal of the Linnean Society 125: 445-462.

WILSON, D. E. \& D. M. REEDER, 2005. Mammal Species of the World: a taxonomic and geographic reference: 3rd.: 1-2142. Johns Hopkins University Press, Baltimore, Maryland.
WILSON, D. E., T. E. LACHER JR. \& R. A. MITTERMEIER, 2016. Handbook of Mammals of the World: vol. 6: Lagomorphs and Rodents I: 1-987. I. Lynx Editions, Barcelona, Spain.

WILSON, D. E., T. E. LACHER JR. \& R. A. MITTERMEIER, 2017. Handbook of Mammals of the World: vol. 7: Rodents II: 1-1008. Lynx Editions, Barcelona, Spain.

ZENG, D., R. K. SWIHART, Y. ZHAO, X. SI \& P. DING, 2019. Cascading effects of forested area and isolation on seed dispersal effectiveness of rodents on subtropical islands. Journal of Ecology 107(3): 1506-1517. DOI: https://doi.org/10.1111/1365-2745.13122 